\title{
Governance, Audit Committee and Strategic Management Accounting in Listed Companies in Vietnam
}

\author{
Huynh LOI ${ }^{1}$, Le Doan Minh DUC ${ }^{*}$, Nguyen Thanh HUNG ${ }^{2}$ \\ ${ }^{1}$ School of Accounting, University of Economics Ho Chi Minh City, Ho Chi Minh city, Vietnam \\ ${ }^{2}$ Binh Duong University, Binh Duong province, Vietnam \\ *Corresponding author: ducldm@ueh.edu.vn
}

\begin{abstract}
Research purpose:

Our research purpose is to explore the relationship of three important components: Corporate Governance, Audit Committee, Strategic Management Accounting.

Research motivation:

Corporate governance includes a system of institutions, policies, and laws in order to effectively organize, operate, and control the company while also ensure the stakeholders' interests. The Audit Committee is a new part of the operating committees of a joint-stock company that performs management and control tasks. On the other hand, strategic management accounting is considered a specialized department or a management tool that plays an increasingly important role in listed joint-stock companies. However, from the literature, there are difficulties in incorporating corporate governance and strategic management accounting in listed companies. The appearance of the Audit Committee will be an effective measure to reduce uncertainty and unnecessary factors that may hinder the application of strategic management accounting.
\end{abstract}

Research design, approach and method:

We use both qualitative and quantitative research methods. We use the Biprobit model on the secondary data obtained from listed companies in Vietnam between 2013 and 2020.

Main findings:

Research results have provided evidences on the existence of the relationship between Corporate Governance, Audit Committee, and Strategic Management Accounting. Corporate governance directly affects strategic management accounting while also indirectly affects strategic management accounting through the Audit Committee. Depending on the characteristics of each listed company (size, number of board members, whether financial statements are audited by the Big 4 or non-Big 4), the company will have to apply different levels of strategic management accounting and audit committee.

Practical/managerial implications:

In order to simultaneously apply strategic management accounting and audit committee, listed companies need to be of larger size, with higher number of board members. When developing and improving strategic management accounting, managers need to combine observations of firm-specific characteristics with the recommendations of the Audit Committee.

Keywords: Corporate Governance, Audit Committee, Strategic Management Accounting, listed companies, Biprobit model, characteristics of a company

\section{INTRODUCTION}

Corporate governance is an essential and vital issue of the company. This issue is expressed through the direction and business operations efficiently and in conformity with the direction (Cadbury, 1992). Corporate governance refers to the interaction between the people performing in the enterprise and the processes used (Monks and Minow, 1995). Corporate governance aims to reach the allocation and use of resources of the enterprise efficiency, consensus, properly oriented. In the trend of economic globalization, businesses receive advantages and challenges for production and business activities. Therefore, corporate governance always has to pose innovative problems, especially the system and management tools. Since then, enterprises have improved the efficiency of global production and business activities. The audit committee has gradually appeared in many joint-stock companies and plays an independent role in the organization. The audit committee helps managers improve risk control, ethical compliance, reliability of financial information. Besides, many businesses are also interested in strategic management accounting and applying it to production and business activities. The purpose is to collect and provide financial and non-financial information inside and outside the enterprise. From there, managers can analyze, evaluate, implement and control business strategies (Cadez and Guilding, 2008) for sustainable development (Thapayom, 2019).

Many studies of academics and professional organizations on three components: corporate governance, audit committee, the strategic management accounting. Most studies focus on the role of each component in the enterprise or the elements 
constituting the effectiveness of each component. In addition, there are also many studies evaluating the impact of each of these components on corporate performance, risk management, or information disclosure. We find that these three components exist simultaneously in a joint-stock company, they must have relationships and interactions with each other. So they need to be discovered for useful exploitation. Through the review, we find that there is still no research on the (i) relationship between corporate governance, audit committee, strategic management accounting, and (ii) their impact. Therefore, we study this relationship based on secondary data with the expectation of discovering new points in theory and practice about the relationship and their impact on listed companies.

\section{METHODOLOGY}

The article uses a combination of qualitative and quantitative research methods. As a first step, we conducted the archival method to review relevant studies and guidelines from three big auditing firms (Deloitte, KPMG, PwC). From there, we identify statements, trends, and design hypotheses. In the next step, we use the Biprobit model to test the hypothesis, evaluate the correlation between the factors and the suitability of the research model. From there, we give the implications.

The data used for testing is secondary data. We collected data from audited financial statements, management reports, other reports published by listed companies. Samples collected conveniently included 240 observers from 30 companies listed on the Stock Exchange in Ho Chi Minh City and Ha Noi City from 2013 to 2020 .

\section{LITERATURE REVIEW}

\subsection{Corporate governance}

Corporate governance is the system of controls, finances, other issues that ensures that a company's managers direct its operations effectively and in the right direction (Cadbury, 1992). Corporate governance consists of a system of leadership and direction on the platform to explain and take responsibility, equal treatment, transparency, vision, ethics. Corporate governance is based on five basic principles for evaluation (Organization for Economic Cooperation and Development (OECD), 1999): (i) Shareholders' rights and key ownership functions; (ii) Fair treatment of shareholders; (iii) Role of stakeholders; (Iv) Disclosure and transparency; (v) Responsibilities of the Board of Directors. Also, corporate governance is based on the interaction between those who perform in the company and the processes used (Monks and Minow, 1995) to achieve consensus in the allocation, effectively using the company's resources in an oriented manner.
The success or failure of corporate governance is greatly influenced by the assessment and selection of components (Elad, Ngan and Bongbee, 2017) in the system and management tools. Corporate governance uses strategic management accounting to increase business performance (Medeckytė and Tamulevičienè, 2020). Therefore, company management will be the underlying cause affecting the formation of the strategic management accounting and disclosure of the strategic management report (Honggowati et al., 2017).

\subsection{Audit committee}

The audit committee originates from the Sarbanes Oxley Act of 2002 and is applied in more than 40 countries around the world. The Audit Committee is a new department that is applied together with other forms of control such as internal control, internal audit in accordance with the trend of international integration. The audit committee promotes the truthfulness and fairness of financial information. The Audit Committee is a member of the Board of Directors, performing some important tasks such as supervising the accounting, finance, risk management and control departments, internal audit, independent audit and internal audit, ethical compliance (Deloitte, 2014; PricewaterhouseCoopers (PwC), 2018; KPMG's Audit Committee Institute, 2017). The audit committee is composed of members who are independent of the organization. Personnel on the Audit Committee are usually appointed by the members of the board of directors. These members should have professional qualifications and knowledge related to the nature of business operations. The audit committee plays a role in increasing the reliability and faithful representation of the financial statements by (i) reviewing the faithful representation, (ii) appointing an independent auditor, and discussing fees, supervise the audit process, resolve audit disagreements.

Audit Committee monitors the financial statements (Khoo, Lim and Monroe, 2020) and impact on the quality of financial statement disclosure or integrated reporting (Agyei-Mensah, 2019; Raimo et al., 2021), management discussion and analysis (Lee and Park, 2019), social responsibility report (Dwekat et al., 2020), sustainability report (Buallay and Al-Ajmi, 2020). In addition, the audit committee affects the price of audit fees (Bala, Amran and Shaari, 2021), reducing audit reporting latency (Raweh et al., 2021), increasing the quality of audit reports (Alhababsah and Yekini, 2021). In addition, the Audit Committee controls risks by (i) monitoring the operation of the internal control department; (ii) monitor the honest and ethical conduct of individuals, conflicts of interest. Furthermore, the Audit Committee (iii) monitoring responsibilities, processes, and the way they implement and disclose risk management. Since then, the Audit Committee directly affects the business performance (Al-Homaidi et al., 2021; Chiu, Chung and Hung, 2021), reducing financial difficulties (Ashraf, Félix and Serrasqueiro, 2021) and earning management (Alzoubi, 2019). 
The audit committee is the bridge of corporate governance to spread the ideas and ways of rational governance. Since then, the Audit Commission promotes the formation and development of strategic management tools appropriately and effectively.

\subsection{Strategic management accounting}

Strategic management accounting is a practical strategic management tool in data analysis to serve the management, implementation, and monitoring of the company's business strategy (Langfield-Smith, 2008). Studies in the field of strategic management accounting often focuses on connecting business activities with markets and competitors in the long term (Guilding, Cravens and Tayles, 2000). Research and application of strategic management accounting can be approached through two perspectives: (i) technical methods of strategic management accounting, (ii) participation of accountants in decision-making processes (Cadez and Guilding, 2008).

Approach technical methods, strategic management accounting is associated with some techniques used for administrative managers (Table 1).

Table 1: The technical methods used by strategic management accounting

\begin{tabular}{|c|c|c|}
\hline Technical methods & Description & Studies \\
\hline Attribute Costing & $\begin{array}{l}\text { Summarize costs associated with product attributes } \\
\text { determined based on customer needs such as safety, } \\
\text { warranty agreement, level of finishes, accessories, } \\
\text { assurance of supply, and after-sales services. }\end{array}$ & $\begin{array}{l}\text { (Guilding, Cravens and } \\
\text { Tayles, 2000) }\end{array}$ \\
\hline Target Costing & $\begin{array}{l}\text { Determine the maximum cost of each product based on } \\
\text { the selling price that can be accepted by the market and } \\
\text { the company's expected profit for production and } \\
\text { business activities. }\end{array}$ & (Darinskaya et al., 2021) \\
\hline Life - Cycle Costing & $\begin{array}{l}\text { Identify and calculate all possible costs for the product } \\
\text { over its entire life cycle, including the costs at the } \\
\text { concept stage, pre-production, costs to be paid by the } \\
\text { buyer. }\end{array}$ & $\begin{array}{l}\text { (Guilding, Cravens and } \\
\text { Tayles, 2000); (Cadez and } \\
\text { Guilding, 2008); (Cinquini } \\
\text { and Tenucci, 2010) }\end{array}$ \\
\hline Quality Costing & $\begin{array}{l}\text { Calculating quality costs related to achieving or not } \\
\text { achieving quality such as: prevention costs, appraisal } \\
\text { costs }\end{array}$ & $\begin{array}{l}\text { (Guilding, Cravens and } \\
\text { Tayles, 2000); (Cadez and } \\
\text { Guilding, 2008); (Cinquini } \\
\text { and Tenucci, 2010); } \\
\text { (Dmitrović-Šaponja and } \\
\text { Suljović, 2017) }\end{array}$ \\
\hline Benchmarking & $\begin{array}{l}\text { Identify and follow the standards, methods, and activities } \\
\text { of effective companies. }\end{array}$ & $\begin{array}{l}\text { (Cadez and Guilding, 2008); } \\
\text { (Cinquini and Tenucci, } \\
\text { 2010); (Dmitrović-Šaponja } \\
\text { and Suljović, 2017) }\end{array}$ \\
\hline Balance Scorecard & $\begin{array}{l}\text { Transform vision and strategy into specific goals and } \\
\text { metrics, through the establishment of a performance } \\
\text { measurement system across four dimensions: financial, } \\
\text { customer, internal business processes, learning - } \\
\text { developing. }\end{array}$ & $\begin{array}{l}\text { (Dmitrović-Šaponja and } \\
\text { Suljović, 2017) }\end{array}$ \\
\hline Strategic Pricing & $\begin{array}{l}\text { Analysis of strategic factors that affect pricing: prices of } \\
\text { competitors, the reaction of competitors, the adaptability } \\
\text { of competitors, the development of markets, and scale of } \\
\text { economies. }\end{array}$ & $\begin{array}{l}\text { (Guilding, Cravens and } \\
\text { Tayles, 2000); (Dmitrović- } \\
\text { Šaponja and Suljović, 2017) }\end{array}$ \\
\hline $\begin{array}{l}\text { Competitor Cost } \\
\text { Assessment }\end{array}$ & Collect, analyze and assess the cost of competitors & $\begin{array}{l}\text { (Guilding, Cravens and } \\
\text { Tayles, 2000); (Cadez and } \\
\text { Guilding, 2008); (Cinquini } \\
\text { and Tenucci, 2010) }\end{array}$ \\
\hline
\end{tabular}




\begin{tabular}{|c|c|c|}
\hline Technical methods & Description & Studies \\
\hline $\begin{array}{l}\text { Competitive Position } \\
\text { Monitoring }\end{array}$ & $\begin{array}{l}\text { Monitor competitive position of competitors such as: } \\
\text { assess and monitor trends in sales, market share, sales } \\
\text { volume, unit cost, Profit-to-sales ratio. }\end{array}$ & $\begin{array}{l}\text { (Guilding, Cravens and } \\
\text { Tayles, 2000); (Cadez and } \\
\text { Guilding, 2008); (Cinquini } \\
\text { and Tenucci, 2010) }\end{array}$ \\
\hline $\begin{array}{l}\text { Competitor Appraisal } \\
\text { Based On Published } \\
\text { Financial Statements }\end{array}$ & $\begin{array}{l}\text { Analyze and evaluate competitors based on disclosure } \\
\text { financial statements. }\end{array}$ & $\begin{array}{l}\text { (Guilding, Cravens and } \\
\text { Tayles, 2000); (Cadez and } \\
\text { Guilding, 2008); (Cinquini } \\
\text { and Tenucci, 2010); } \\
\text { (Dmitrović-Šaponja } \\
\text { Suljović, 2017) }\end{array}$ \\
\hline $\begin{array}{l}\text { Customer Profitability } \\
\text { Analysis }\end{array}$ & $\begin{array}{l}\text { Determine the contribution of each customer, customer } \\
\text { group in achieving the company's profits. }\end{array}$ & (Cadez and Guilding, 2008) \\
\hline $\begin{array}{l}\text { Valuation of customers as } \\
\text { assets }\end{array}$ & $\begin{array}{l}\text { Calculate the present value of all future profit flow from } \\
\text { a particular customer or group of customers. }\end{array}$ & $\begin{array}{l}\text { (Guilding, Cravens and } \\
\text { Tayles, 2000); (Cadez and } \\
\text { Guilding, 2008) }\end{array}$ \\
\hline
\end{tabular}

(Source: Synthesize previous studies)

Strategic management accounting techniques, if used effectively, will improve operational performance and stability of operational performance. (Thapayom, 2019), (Phornlaphatrachakorn and Na-Kalasindhu, 2020), investment efficiency (Pylypiv and Piatnychuk, 2018), increasing competitive advantage in global production and business activities (Abdelraheem and Hussaien, 2021).

There are many studies that recognize and acknowledge the importance of strategic management accounting. However, in the world, companies have not yet properly applied and disclosed information about strategic management accounting. For example, in Indonesia, the level of disclosure is $39.4 \%$, in Lithuanian awareness and application of strategic management accounting is low due to the lack of necessary preparation time (Medeckyte and Tamulevičienè, 2021). The reason for this problem comes from the impact of many different factors, many of which are very vague in management. Therefore, managers need to observe and choose to make appropriate adjustments, such as business size, business strategy, level of competition, the participation of accountants in the decision-making process (Chi, 2021), information systems and organizational culture (Hadid and Al-Sayed, 2021), application of information technology and data mining (Ping, 2021).

\section{THE RESEARCH MODELS AND DATA}

\subsection{Research model and hypothesis}

Three important components: Corporate Governance, Audit Committee, and Strategic Management Accounting that exist in a company are necessary and consistent with the trend of international integration. Therefore, the relationship between these three components has specific tests. We take this approach and collect data including 240 observations from listed companies on the Ho Chi Minh City Stock Exchange and the Hanoi Stock Exchange from 2013 to 2020. The following proposed model shows the relationships and impacts between corporate governance, audit committee, and strategic management accounting (Picture 1).

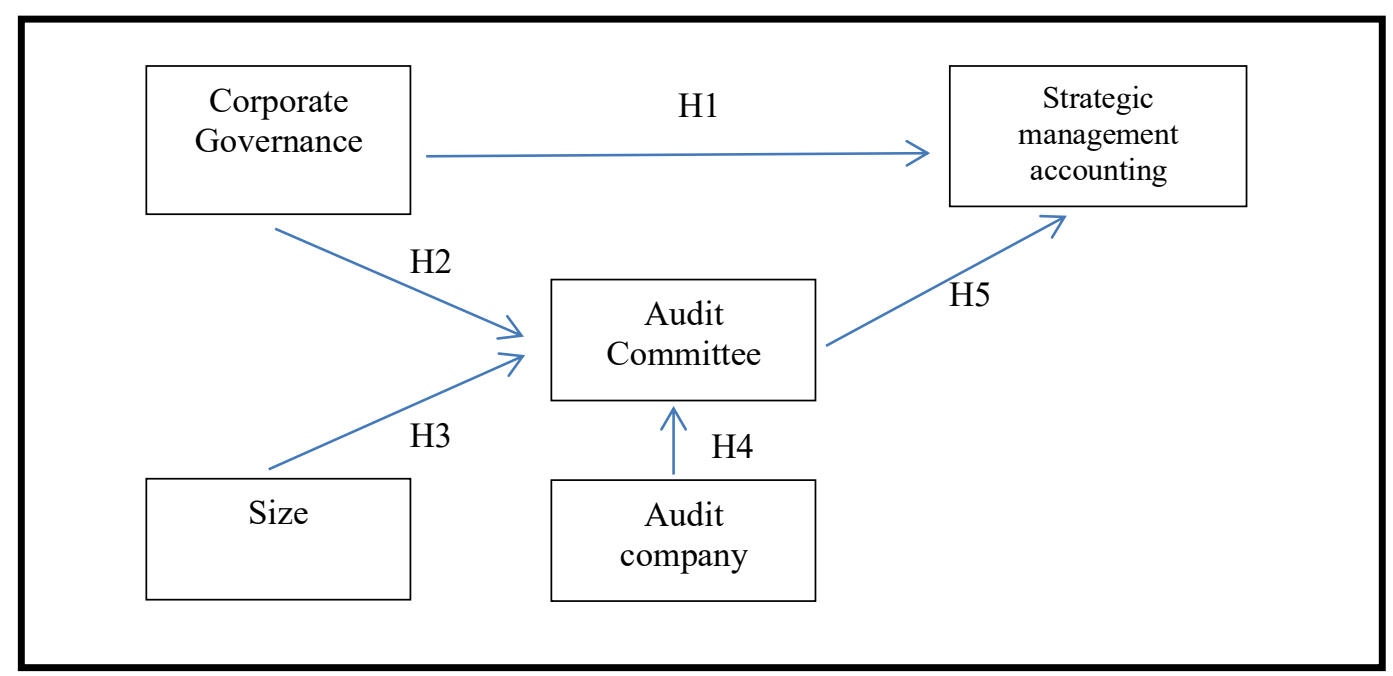

Picture 1. Proposed model

(Source: authors' development) 
The capital owner's representative is the Board of Directors. Board using corporate governance in the operation of enterprises, meet the plan and strategy. The Board of Directors authorizes the manager to directly organize and carry out business activities. At the same time, the board promotes the development of strategic management tools (Honggowati et al., 2017). Therefore, corporate governance promotes the application of strategic management accounting in production and business activities (Arunruangsirilert and Chonglerttham, 2017).

[H1]: Corporate governance has an impact on strategic management accounting.

In addition, the Board of Directors also needs an independent department or independent mechanism for monitoring and control to enhance operational efficiency, compliance, and information reliability. This department is an audit committee that is under the board. Therefore, corporate governance promotes the establishment of the Audit Committee (Ali and Meah, 2021).

[H2]: Corporate governance has an impact on the establishment of the Audit Committee.

When the size of the enterprise is large enough, it will promote the establishment, maintenance of existence, and promote the role of the Audit Committee. Therefore, firm size is an important factor influencing the establishment of the audit committee (F Neumann R Mautz, 1977). Therefore, the larger the enterprise size, the more promoting the formation of the Audit Committee (Paul Collier, 1992) because the benefits from the audit committee's supervision are much higher than the costs to maintain the audit committee.

[H3]: The size of the company affects the establishment of the audit committee.

The audit committee increases the independence of the auditors (Peter W. Wolnizer, 1987), thereby increasing the quality of the audit. The larger the size and reputation of the independent auditing firms, the more businesses are encouraged to set up an audit committee (Lynn, 1985) to facilitate their audit work and assist in increasing the reliability and transparency of financial information. Therefore, the size and reputation of the audit firm are related to the formation of the audit committee in the company.

\section{[H4]: The size and reputation of the audit firm influences the establishment of the Audit Committee}

The business environment is increasingly open and rapidly changing factors from the external and internal business environment. The external environment of the enterprise such as macro factors, industry competition. The internal environment of the enterprise such as resources, structure, strategy, and operational processes. These factors positively affect strategic management tools in finding and maintaining competitive advantages and sustainable development. Besides, strategic management accounting is a very complex field and paradox. Strategic management accounting is very practical. However, applying successful strategic management accounting requires awareness, appropriate selection to eliminate the uncertain problems. Therefore, the Audit Committee is a department that filters and supports the success of use of strategic management accounting techniques. Since then, the Audit Committee has contributed to both promoting the formation and effective selection of strategic management accounting techniques. The Audit Committee can be a department that helps businesses use tools for sustainable development. (Bunget et al., 2020).

\section{[H5]: Audit committee impacts the application of strategic management accounting.}

\subsection{The scale}

We developed the scale from previous studies and adapted it to the Vietnamese context (Table 2). We use a scale from secondary data.

\begin{tabular}{|c|l|c|l|l|l|}
\hline Ordinal & Concept & Variable & The scale & Collect data & $\begin{array}{l}\text { The basis for } \\
\text { scale }\end{array}$ \\
\hline 1 & $\begin{array}{l}\text { Audit } \\
\text { Committee }\end{array}$ & ACM & $\begin{array}{l}\text { Audit committee exists in } \\
\text { the enterprise, measured } \\
\text { by 1 if present, 0 if not. }\end{array}$ & $\begin{array}{l}\text { Management report } \\
\text { or annual report }\end{array}$ & $\begin{array}{l}\text { Authors' } \\
\text { opinions }\end{array}$ \\
\hline 2 & $\begin{array}{l}\text { Strategic } \\
\text { management } \\
\text { accounting }\end{array}$ & SMA & $\begin{array}{l}\text { Enterprises use one of the } \\
\text { technical methods of } \\
\text { strategic management } \\
\text { accounting, measured by }\end{array}$ & $\begin{array}{l}\text { The company } \\
\text { disclosures a } \\
\text { strategic } \\
\text { management }\end{array}$ & $\begin{array}{l}\text { Authors' } \\
\text { opinions }\end{array}$ \\
\hline
\end{tabular}




\begin{tabular}{|c|c|c|c|c|c|}
\hline Ordinal & Concept & Variable & The scale & Collect data & $\begin{array}{l}\text { The basis for } \\
\text { scale }\end{array}$ \\
\hline & & & 1 if present, 0 if not. & $\begin{array}{l}\text { accounting report } \\
\text { integrated in the } \\
\text { sustainability report } \\
\text { or annual report }\end{array}$ & \\
\hline 3 & $\begin{array}{l}\text { Audit } \\
\text { committee }\end{array}$ & GOV & $\begin{array}{l}\text { The number of members } \\
\text { of the Board of Directors } \\
\text { is appointed annually }\end{array}$ & Management report & $\begin{array}{l}\text { (Brown and } \\
\text { Caylor, 2006) }\end{array}$ \\
\hline 4 & $\begin{array}{l}\text { Size of the } \\
\text { business }\end{array}$ & SIZE & $\begin{array}{l}\text { Size of the company } \\
\text { expressed in assets of the } \\
\text { company, measured in } \\
\text { Ln(assets) }\end{array}$ & $\begin{array}{l}\text { Audited financial } \\
\text { statements }\end{array}$ & $\begin{array}{l}\text { (Brown and } \\
\text { Caylor, 2006) }\end{array}$ \\
\hline 5 & Audit firm & AUC & $\begin{array}{l}\text { Size and reputation of the } \\
\text { audit firm performing the } \\
\text { audit, Measured by } 1 \text { : } \\
\text { Big } 4 \text { and } 0 \text { : non Big } 4\end{array}$ & Audit report & $\begin{array}{l}\text { (Brown and } \\
\text { Caylor, 2006) }\end{array}$ \\
\hline
\end{tabular}

(Source: Author developed from previous studies)

We collect secondary data to measure proxy variables. These data are collected from audited financial statements, management reports, audit reports, sustainability reports that are published on the stock exchange.

\section{RESULTS AND DISCUSSION}

5.1. Current status of corporate governance, audit committee and strategic management accounting in listed companies in Vietnam
In order to have analysis and assessment of the current situation of corporate governance, the Audit Committee, and the picture of strategic management accounting in joint stock companies, the article is evaluated through data from the observed sample (Table 3) and from current news. The sample is 240 observations collected from 30 listed companies over 8 years (from 2013 to 2020). The selection of the listed companies was done through convenience sampling.

Table 3. Applying governance, Audit Committee, strategic management accounting in listed companies 2013-2020

\begin{tabular}{|c|c|c|c|c|c|c|}
\hline \multirow[b]{2}{*}{ Year } & \multicolumn{2}{|c|}{ Corporate governance } & \multicolumn{2}{|c|}{ Audit Committee } & \multicolumn{2}{|c|}{$\begin{array}{c}\text { Strategic management } \\
\text { accounting }\end{array}$} \\
\hline & $\begin{array}{l}\text { Number of } \\
\text { companies } \\
\text { applying }\end{array}$ & $\%$ & $\begin{array}{l}\text { Number of } \\
\text { companies } \\
\text { applying }\end{array}$ & $\%$ & $\begin{array}{l}\text { Number of } \\
\text { companies } \\
\text { applying }\end{array}$ & $\%$ \\
\hline 2013 & 30 & 100 & 0 & 0 & 0 & 0 \\
\hline 2014 & 30 & 100 & 1 & 3 & 0 & 0 \\
\hline 2015 & 30 & 100 & 1 & 3 & 0 & 0 \\
\hline 2016 & 30 & 100 & 3 & 10 & 0 & 0 \\
\hline 2017 & 30 & 100 & 8 & 27 & 6 & 20 \\
\hline 2018 & 30 & 100 & 10 & 33 & 10 & 33 \\
\hline 2019 & 30 & 100 & 11 & 37 & 15 & 50 \\
\hline 2020 & 30 & 100 & 12 & 40 & 15 & 50 \\
\hline
\end{tabular}

(Source: Synthesized from 240 observations)

\section{Governance}

Corporate governance has received a lot of attention recently, especially at listed companies, to meet the information disclosure regulations of the Securities Commission. In the context of international integration and global competition, companies always actively innovate corporate governance, in line with international practices. In addition, the State supports companies to improve corporate governance efficiency. The Vietnam Corporate Governance Initiative (VCGI) was launched in December 2016 by the International Finance Corporation (IFC), the Ho Chi Minh Stock Exchange (HOSE), the Hanoi Stock Exchange (HOSE), with the support of the State Securities Commission of Vietnam (SSC). Recently, on 24/01/2018, Ho Chi Minh City Stock Exchange organized the program "Training for Listed Companies on Holding Annual General Meeting of Shareholders in 2018 and new regulations on Governance the company". The program is within the framework of the 
VCGI. The program aims to promote the application of good corporate governance practices in the stock market.

According to survey data at listed companies in Vietnam, all listed companies use corporate governance tools and disclosure annual management reports to the Stock Exchange and stakeholders (Table 3 ). This shows that listed companies are aware of the essential role of corporate governance in the organization, operation, and strategy of the business, meeting the requirements of disclosure for stakeholders.

\section{Audit Committee}

Joint-stock companies in Vietnam, when established, have a governance structure consisting of a board of directors and a board of supervisors. In the period 2014-2017, a few listed companies saw the role of the Audit Committee, so they actively transformed the structure of the board of supervisors into an Audit Committee. The number of companies establishing Audit Committees increased gradually in the period of 2018-2019. In 2020, the state issued new Enterprise Law to create a legal framework for joint-stock companies selected board of supervisors or the Audit Committee in the management structure. Since then, many listed companies have changed their management structure from the supervisory board or internal audit subcommittee to the audit committee.

From the observed sample (Table 3), it shows that from 2013 to 2020, the percentage of listed companies setting up an audit committee increases to $40 \%$. This shows that listed companies are aware of the important position and role of the Audit Committee.

\section{Strategic management accounting}

In Vietnam, many authors have studied the application of strategic management accounting in companies. The level of application of strategic management accounting techniques, in Vietnam (V Tran Hong \& L Tran Thi Phuong, 2020) is less than 20\%, lower than that of enterprises in developed countries such as Australia, Greece, Malaysia, Serbia, Italy (over 50\%); in developing countries like Thailand (over 20\%). When approaching each technical method in detail, there are many useful technical methods that are still not used in companies ((Hoang Thu Hien, 2017); (Nguyen Minh Thanh, 2017), (Hoang Thi Huyen, 2018), (Dang Nguyen Manh, 2019), (To Minh Thu, 2019), (Nguyen Thi Duc Loan, 2019)).

From observations of listed companies (Table 3), listed companies have used the technical methods of strategic management accounting over the years. Observed in $2020,50 \%$ of them have used strategic management accounting techniques.

\subsection{Description of the sample}

Research data is collected from 30 listed companies on Ho Chi Minh Stock Exchange and Hanoi Stock Exchange from 2013 to 2020. The test data has 240 observations (Table 4).

Table 4. Summary statistics

\begin{tabular}{|r|rrrrr|}
\hline \multirow{2}{*}{ Variable } & Obs & Mean & Std. Dev. & Min & Max \\
\hline GOV & 240 & 6 & 2 & 3 & 12 \\
AUC & 240 & 1 & 0 & 0 & 1 \\
ACM & 240 & 0 & 0 & 0 & 1 \\
SMA & 240 & 0 & 0 & 0 & 1 \\
SIZE & 240 & 28.32 & 2.33 & 23.79 & 34.82 \\
\hline
\end{tabular}

Listed companies have the number of members of the Board of Directors from 3 to 12 members, the average number of members is 6 . Size is represented by LN (assets) with an average number of 28.32, ranges from 23.79 to 34.82 . The remaining factors are Big4 audit firm, Audit Committee, strategic management accounting measured by the value 1 if applicable and 0 if not applied.

\subsection{Model selection}

The following econometric specification is used to test the hypothesis about the relationship between company governance, auditing committee and strategic management accounting as follows:

$$
\begin{aligned}
& \mathrm{ACM}=\beta+\alpha 1 \mathrm{GOV}+\alpha 2 \\
& \mathrm{SIZE}+\alpha 3 \mathrm{AUC}(1) \\
& \mathrm{SMA}=\beta+\alpha 1 \mathrm{GOV}+\alpha 2 \\
& \mathrm{ACM}(2)
\end{aligned}
$$

With the following characteristics: (i) The dependent and endogenous variables in the model are binary. (ii) The values of the two dependent variables SMA and $\mathrm{ACM}$ in the two equations are likely to be correlated. We check the correlation coefficient in Table 5 below. If there is a correlation, we can use the Biprobit model. In the opposite result, we can use two separate probit models. 
Table 5. Correlation matrix

\begin{tabular}{|l|lllll|}
\hline & GOV & \multicolumn{1}{c|}{ AUC } & ACM & SMA & SIZE \\
\hline GOV & 1.0000 & & & & \\
AUC & $0.4433 *$ & 1.0000 & & & \\
ACM & 0.2734 * & $0.1842 *$ & 1.0000 & & \\
SMA & 0.2681 * & 0.2496 * & $0.6504 *$ & 1.0000 & \\
SIZE & $0.6358 *$ & 0.4617 * & $0.4589 *$ & $0.3549 *$ & 1.0000 \\
\hline
\end{tabular}

The results of Table 5 show that there is a correlation between the variables (GOV, AUC, ACM, SMA, SIZE). This result reflects the model fit. Therefore, we use Biprobit model instead of OLS, 2SLS regression model or separate probit models. However, to ensure the suitability of the Biprohit model with the research model, we conduct a Biprobit fit test.

Table 6. Estimation results Biprobit

\begin{tabular}{|c|c|c|c|c|c|c|}
\hline & Coef. & $\begin{array}{l}\text { Robust } \\
\text { Std. Err. }\end{array}$ & z & $P>|z|$ & [95\% Conf. & Interval] \\
\hline \multicolumn{7}{|l|}{ SMA } \\
\hline $\begin{array}{r}\text { GOV } \\
\text { cons }\end{array}$ & $\begin{array}{r}.1864914 \\
-2.075012\end{array}$ & $\begin{array}{l}.0480477 \\
.3219248\end{array}$ & $\begin{array}{r}3.88 \\
-6.45\end{array}$ & $\begin{array}{l}0.000 \\
0.000\end{array}$ & $\begin{array}{r}.0923196 \\
-2.705973\end{array}$ & $\begin{array}{r}.2806632 \\
-1.444051\end{array}$ \\
\hline \multicolumn{7}{|l|}{$\mathrm{ACM}$} \\
\hline GOV & .0702562 & .058174 & 1.21 & 0.227 & -.0437627 & .1842751 \\
\hline SIZE & .2225937 & .0472126 & 4.71 & 0.000 & .1300588 & .3151287 \\
\hline AUC & -.2899278 & .2001281 & -1.45 & 0.147 & -.6821716 & .1023161 \\
\hline _cons & -7.558062 & 1.20075 & -6.29 & 0.000 & -9.911488 & -5.204635 \\
\hline lathrho & 1.329559 & .2035686 & 6.53 & 0.000 & .9305716 & 1.728546 \\
\hline rho & .8691415 & .0497915 & & & .7308603 & .9388839 \\
\hline Wald test of & $=0: \operatorname{chi} 2(1)$ & $=42.6573$ & & & Prob $>$ chi2 & $2=0.0000$ \\
\hline
\end{tabular}

(Source: Calculations from Stata)

From Table 6, it can be seen that the correlation coefficient between the two equations SMA and ACM is 0.869 (correlation coefficient - rho) and is statistically significant at $95 \%$. That shows that there is a correlation between the two equations. Therefore, using the Biprobit model is appropriate compared with the probit model for each separate equation.

\subsection{Testing result}

The Biprobit model has the following characteristics: (i) The dependent and endogenous variables in the model are binary. (ii) The values of two dependent variables SMA and ACM in the two equations are likely to be correlated. We proceed to calculate the prediction probabilities in the following order:

First, marginal predicted probability (or possibility $S M A=1, A C M=1)$, the following results (Table 7):

Table 7. Research results Forecast probability margin

\begin{tabular}{|r|rrrrr|}
\hline Variable & Obs & Mean & Std. Dev. & Min & Max \\
\hline SMA & 240 & .1916667 & .3944348 & 0 & 1 \\
SMA1 & 240 & .1872363 & .1074339 & .0648181 & .5646955 \\
ACM & 240 & .1916667 & .3944348 & 0 & 1 \\
ACM1 & 240 & .1888332 & .1601965 & .0237346 & .7089804 \\
\hline
\end{tabular}

(Source: Calculations from Stata) 
Second, calculate the combined predictive probabilities of the cases.

- $\quad \mathrm{SMA}=0$ và $\mathrm{ACM}=0$, (a)

- $\mathrm{SMA}=0$ và $\mathrm{ACM}=1,(\mathrm{~b})$

- $\quad \mathrm{SMA}=1$ và $\mathrm{ACM}=0,(\mathrm{c})$

- $\mathrm{SMA}=1$ và $\mathrm{ACM}=1(\mathrm{~d})$
The results of Table 8 show that the probability of situation (a), (b), (c) and (d) is $74.9 \%, 6.3 \%, 61.7 \%$, and $12.5 \%$ (Mean value). Thus, there is a very high probability that companies lack an audit committee and strategic management accounting.

Table 8. Calculate the combined forecast probabilities

\begin{tabular}{|c|ccccc|}
\hline Variable & Obs & Mean & Std. Dev. & Min & Max \\
\hline proo & 240 & .7494354 & .1523107 & .2847969 & .930096 \\
pro1 & 240 & .0633284 & .0786084 & .0023792 & .3905553 \\
pr10 & 240 & .0617314 & .0399439 & .0015088 & .2321917 \\
pr11 & 240 & .1255049 & .1009747 & .0212784 & .4393118 \\
\hline
\end{tabular}

Third, we calculate the marginal effects according to the explanatory variables GOV, SIZE and AUC for the above 4 cases as follows:

Case (a). Probability for $\mathbf{S M A}=\mathbf{0}$ and $\mathbf{A C M}=\mathbf{0}$. The results from Table 9 show the $\mathrm{dy} / \mathrm{dx}$ values: $\mathrm{GOV}<0$;
$\mathrm{SIZE}<0 ; \mathrm{AUC}>0$. This result reflects that other factors being held constant (or the average value of variables), the size of a company is small, the number of boards is low or the company uses Big4's audit service will increase the probability that $\mathrm{SMA}=0$ and $\mathrm{ACM}=0$.

Table 9. Estimation results case (a)

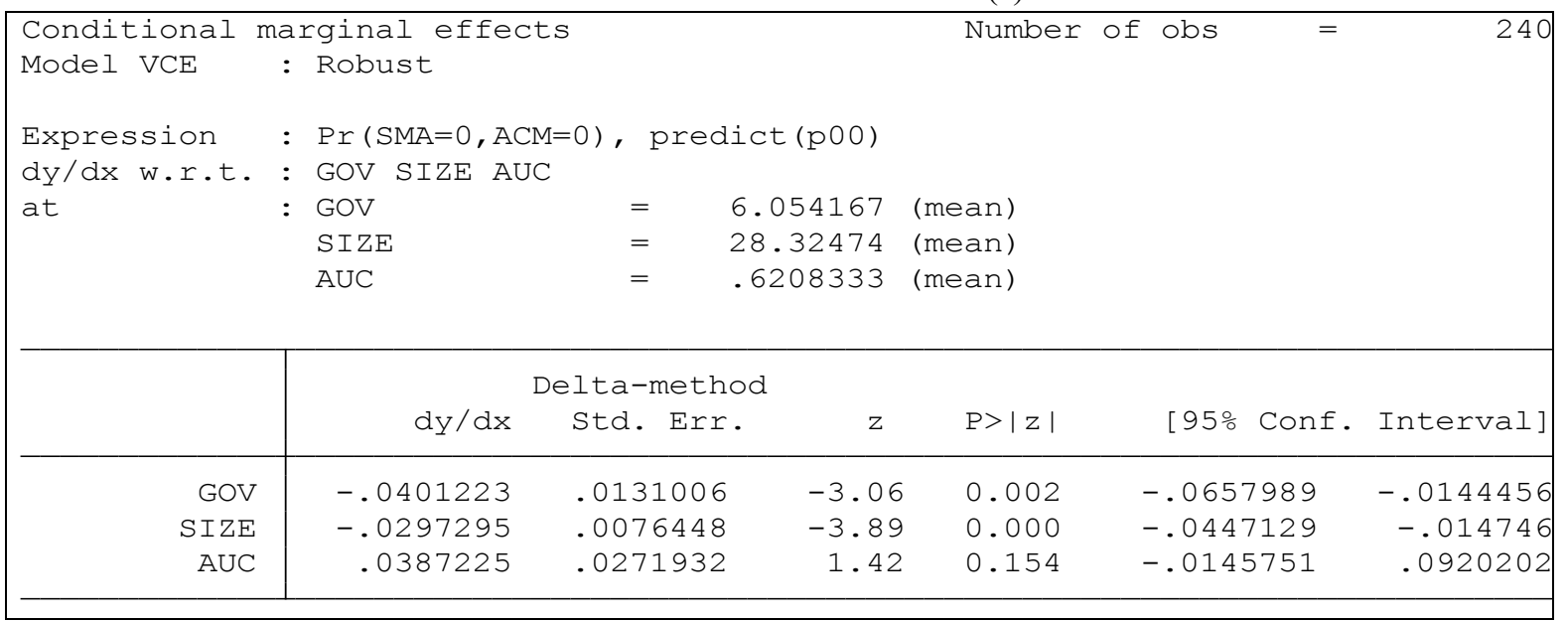

(Source: Calculations from Stata)

Case (b). Probability for $\mathbf{S M A}=0$ and $\mathbf{A C M}=1$. The results from Table 10 describe the $\mathrm{dy} / \mathrm{dx}$ values: $\mathrm{GOV}<0 ;$ SIZE $>0 ; \mathrm{AUC}<0$. This result reflects that other factors being held constant (or the average value of variables), the size of a company is large, the number of boards is low or the company uses nonBig4's audit service will increase the probability that $\mathrm{SMA}=0$ and $\mathrm{ACM}=1$.

Table 10. Estimation results case (b)

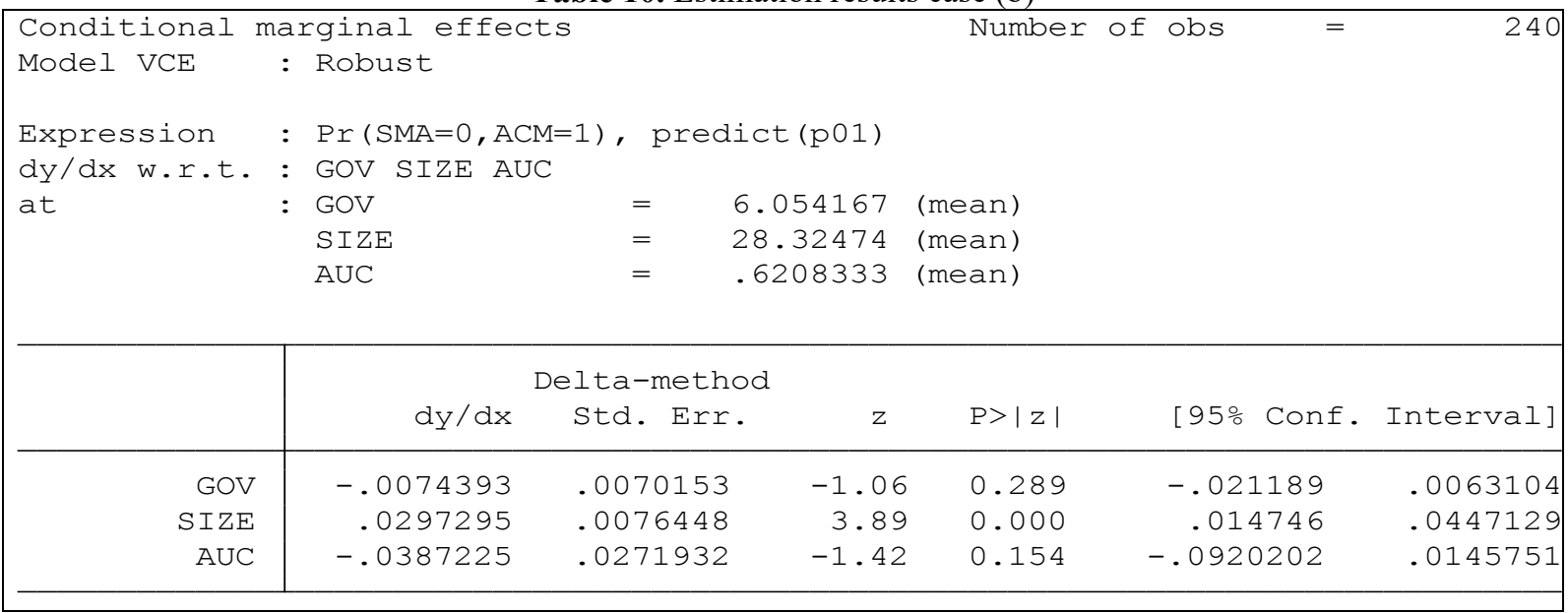


(Source: Calculations from Stata)

Case (c). Probability for $\mathbf{S M A}=1$ and $\mathbf{A C M}=\mathbf{0}$. The results from Table 11 describe the $\mathrm{dy} / \mathrm{dx}$ values: GOV $>0 ;$ SIZE $<0 ; A U C>0$. This result reflects that other factors being held constant (or the average value of variables), the size of a company is small, the number of boards is high or the company uses Big4's audit service will increase the probability that $\mathrm{SMA}=1$ and $\mathrm{ACM}=0$.

Table 11. Estimation results case (c)

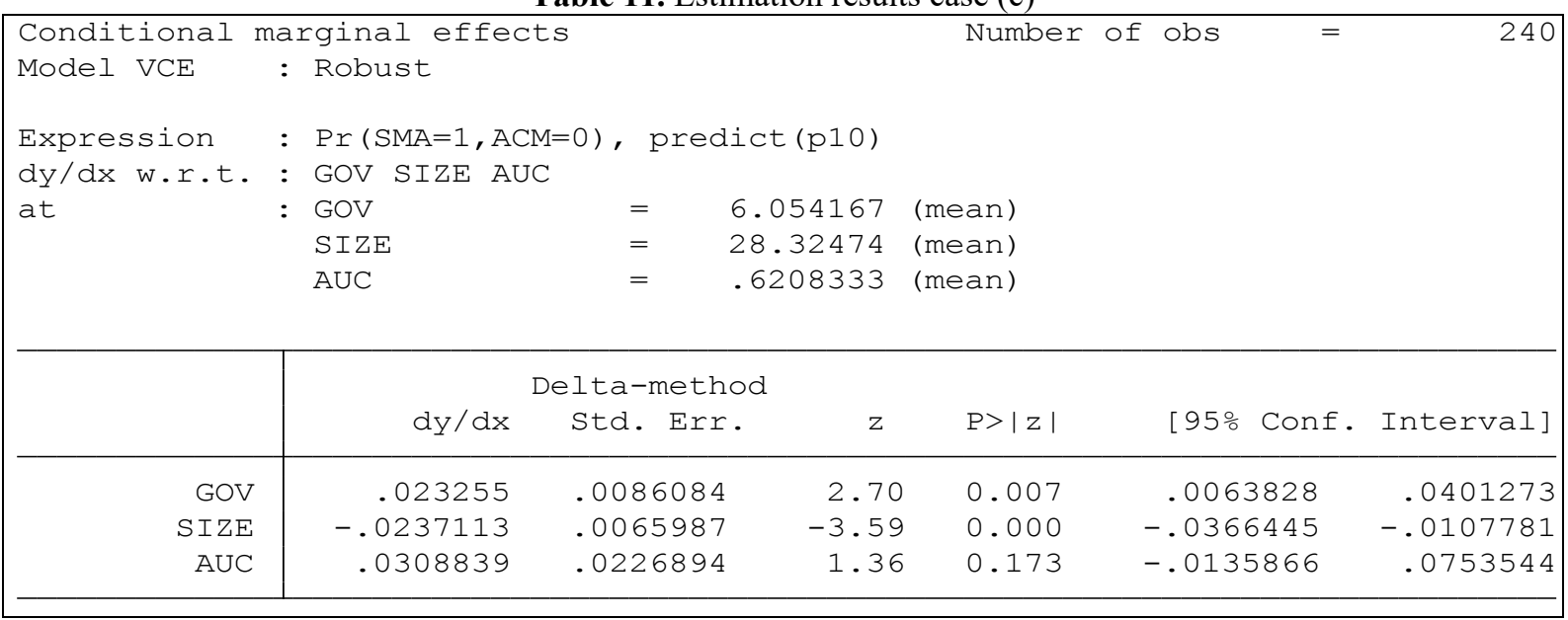

(Source: Calculations from Stata)

Case (d). Probability for $\mathbf{S M A}=1$ and $A C M=1$. The results from Table 12 describe the $\mathrm{dy} / \mathrm{dx}$ values: GOV $>0 ;$ SIZE $>0 ; A U C<0$. This result reflects that other factors being held constant (or the average value of variables), the size of a company is large, the number of boards is high or the company uses nonBig4's audit service will increase the probability that $\mathrm{SMA}=1$ and $\mathrm{ACM}=1$.

Table 12. Estimation results case (d)

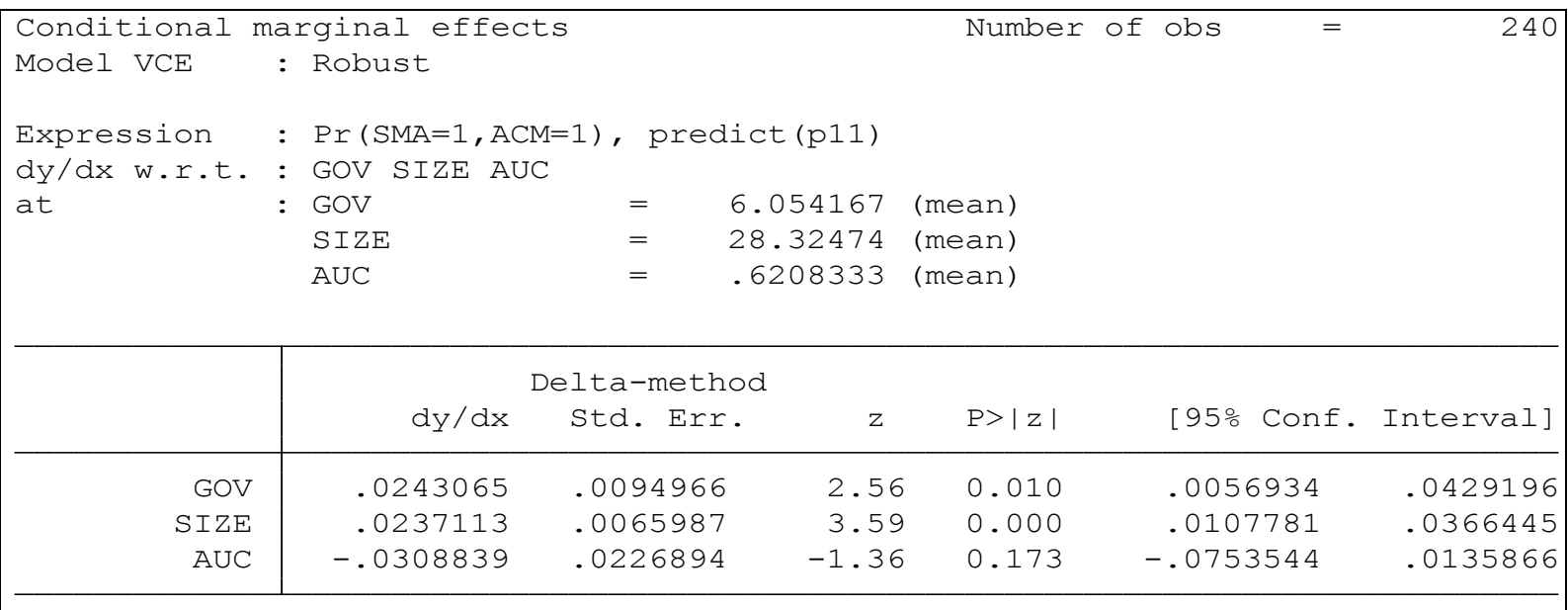

(Source: Calculations from Stata)

\section{IMPLY}

The above results of the study demonstrated three main issues:

(i) The existence of the relationship between corporate governance, audit committee, strategic management accounting is realistic and necessary (Table 5); (ii) The simultaneous impact of corporate governance on the formation of the audit committee and strategic management accounting (from Table 7 to Table 12).

(iii) Depending on the characteristics of each listed company: The size of the company, the number of members of the board of directors, the size and reputation of the audit firm, the 
listed company will have the adoption of the strategic management system and the audit committee (from Table 9 to Table 12).

With the above evidence, the appearance of corporate governance, audit committee, strategic management accounting in a joint-stock company is reasonable, in line with current trends in the world, with estimates and policies on management structure and governance in joint-stock companies in Vietnam. The establishment of the Audit Committee is influenced by corporate governance, size of the company, and audit firm. At the same time, Audit Committee screening impact strategic management accounting. The above evidence not only reaffirms the direct relationship between corporate governance and strategic management accounting as many previous studies have published. Moreover, we show a new component in the relationship is the formation of the Audit Committee. Therefore, the audit committee is also a factor affecting strategic management accounting that needs attention in the organization, application, and development of strategic management accounting in joint-stock companies.

From these results, we imply the following issues to consolidate the management apparatus, control system development in the joint-stock company in Vietnam:

(1) Acknowledge and quickly organize and develop corporate governance components. Audit Committee, Strategic Management Accounting, Corporate Governance are issues that have been universally recognized. Therefore, companies need to perfect and develop corporate governance to a new level, in line with contemporary thinking, organizational forms of management, and management technology. The audit committee is a new department that needs to be researched and quickly deployed in accordance with the governance background, company size, and impacts from audit firms. Since then, the Audit Committee has promptly assumed and promoted its role in joint-stock companies. This issue is not a fairly new one, or lacks a legal framework. This issue has been proven in practice in countries around the world and has also been promoted by the State with policies and guidelines. Therefore, companies need to acknowledge and quickly update information to proceed. Finally, it is time to recognize and quickly develop the strategic management accounting department to solve the problem of strategic management tools. Managers need to quickly apply strategic management accounting to replace and improve tools for providing management information in joint-stock companies. This issue is no longer the time for procrastination in joint-stock companies. Because of the factors from the macro environment, the industry competitive environment, inside environment of the joint-stock companies have changed too much. These factors pose challenges to corporate governance in the direction of quickly connecting and harmonizing with competitors and the production and business environment.
(2) It is necessary to review the governance system in joint-stock companies. This is the problem is not a new issue. However, it is a bottleneck in the process of development in management, finance, auditing, accounting, strategic management accounting tools. Many studies have mentioned this bottleneck in theory and practice. In our opinion, at present, corporate governance needs to solve two problems. They are thinking and management technology. It's time for company managers, especially in Vietnam, to properly position themselves in the global business. They are strategically and responsibly doing business in a relationship that adapts quickly to the business environment. With that perspective, corporate governance must be based on appropriate management technology. Management technology needs to innovate from classic and traditional management technology on the basis of manual and semi-manual processing to modern management on the basis of automation technology and digital links. The previous studies and above evidence of strategic management accounting that we have introduced have shown that strategic management accounting is very necessary. However, strategic management accounting is only the result of the impact of management. If corporate governance raised a new level of thinking, management technology will form a new foundation. This foundation pushes and contributes to solving the "paradox" problem (Nixon and Burns, 2012) of strategic management accounting between theory and applied reality. From there, managers gradually organize and develop some management accounting techniques such as activitybased costing techniques, and performance measurement techniques through the balanced scorecard, and cost analysis techniques of competitors...

(3) It is necessary to accept and quickly organize, develop and complete the Audit Committee. The audit committee will assume two important roles. Firstly, it performs the main role of overseeing the accounting, finance, risk control, internal audit, independent audit, and compliance departments. Next, through the control process, the Audit Committee will also find out the defects of the departments, the tools providing information such as strategic management accounting. This is our interesting finding in this study, a new factor affecting strategic management accounting. In the previous studies, when discussing strategic management accounting, researchers often focused on the factors and foundations of management such as environmental uncertainty, market orientation, business strategy, competition, the participation of accountants in management decision making, decentralization of management, quality of information systems (Pavlatos, 2015). The appearance of the Audit Committee will be a new filter. This filter reduces uncertainty and unnecessary factors affecting the application of strategic management accounting, improving the certainty and feasibility of strategic management accounting. 
(4) When developing and perfecting strategic management accounting, managers need to combine observations of general influencing factors (such as environmental uncertainty, market orientation, business strategy, competition, participation of accountants in management decision making, decentralization of management, quality of information systems...) with the recommendations of the Audit Committee. The purpose is to filter out unnecessary and inappropriate elements for management and control. For example, when managers use activity-based costing or balanced scorecards, they should consult the advice of audit committee. The audit committee will assess whether this tool is necessary and suitable for the company's needs for governance control and risk management.

Currently, corporate governance, audit committee, strategic management accounting are the components that deeply need attention and approach in joint-stock companies. Our empirical evidence has initially explained the existence and relationships of these components in listed companies at a certain time. This relationship shows the direct impact of corporate governance on strategic management accounting. At the same time, the formation of the Audit Committee also created a new impact on strategic management accounting. Our research is only carried out in the early stages in a certain scope. We have not identified and proven the criteria that the Audit Committee uses to filter out risks for strategic management accounting. We look forward to the contributions of readers, specialized scientists.

\section{CONCLUSION}

Research results have provided evidence on the existence of the relationship between Corporate Governance - Audit Committee - Strategic Management Accounting. Corporate governance not only directly affects strategic management accounting but also indirectly affects strategic management accounting through the Audit Committee. From there, listed companies need a large size, a large number of board members to simultaneously apply strategic management accounting and audit committee.

\section{REFERENCES}

[1] Abdelraheem, A. A. E. and Hussaien, A. M. (2021) 'Impact of strategic managerial accounting techniques on the competitive advantage of sudanese exports in light of globalization', International Journal of Advanced and Applied Sciences, 8(2). doi: 10.21833/ijaas.2021.02.009.

[2] Agyei-Mensah, B. K. (2019) 'The effect of audit committee effectiveness and audit quality on corporate voluntary disclosure quality', African Journal of Economic and Management Studies, 10(1), pp. 17-31. doi: 10.1108/AJEMS-04-2018-0102.

[3] Al-Homaidi, E. A. et al. (2021) 'The influence of corporate governance characteristics on profitability of Indian firms: An empirical investigation of firms listed on Bombay stock exchange', Investment Management and Financial Innovations, 18(1), pp. 114-125. doi: 10.21511/imfi.18(1).2021.10.

[4] Alhababsah, S. and Yekini, S. (2021) 'Audit committee and audit quality: An empirical analysis considering industry expertise, legal expertise and gender diversity', Journal of International Accounting, Auditing and Taxation, $42 . \quad$ doi: 10.1016/j.intaccaudtax.2021.100377.

[5] Ali, M. H. and Meah, M. R. (2021) 'Factors of audit committee independence: An empirical study from an emerging economy', Cogent Business and Management, $\quad 8(1)$ doi: 10.1080/23311975.2021.1888678.

[6] Alzoubi, E. S. S. (2019) 'Audit committee, internal audit function and earnings management: evidence from Jordan', Meditari Accountancy Research, 27(1), pp. 72-90. doi: 10.1108/MEDAR-06-20170160 .

[7] Arunruangsirilert, T. and Chonglerttham, S. (2017) 'Effect of corporate governance characteristics on strategic management accounting in Thailand', Asian Review of Accounting, 25(1). doi: 10.1108/ARA-112015-0107.

[8] Ashraf, S., Félix, E. G. S. and Serrasqueiro, Z. (2021) 'Does board committee independence affect financial distress likelihood? A comparison of China with the UK', Asia Pacific Journal of Management. doi: 10.1007/s10490-020-09747-5.

[9] Bala, H., Amran, N. A. and Shaari, H. (2021) 'Audit committee and financial reporting quality: The mediating effect of audit price in Nigeria', Afro-Asian Journal of Finance and Accounting, 11(2), pp. 167197. doi: 10.1504/AAJFA.2021.113554.

[10] Brown, L. D. and Caylor, M. L. (2006) 'Corporate governance and firm valuation', Journal of Accounting and Public Policy, 25(4). doi: 10.1016/j.jaccpubpol.2006.05.005.

[11] Buallay, A. and Al-Ajmi, J. (2020) 'The role of audit committee attributes in corporate sustainability reporting: Evidence from banks in the Gulf Cooperation Council', Journal of Applied Accounting Research, 21(2), pp. 249-264. doi: 10.1108/JAAR-062018-0085.

[12] Bunget, O. C. et al. (2020) 'The link between board structure, audit, and performance for corporate sustainability', Sustainability (Switzerland), 12(20), pp. 1- 
27. doi: 10.3390/su12208408

[13] Cadbury, A. (1992) Report of the committee on the financial aspects of corporate governance, Gee.

[14] Cadez, S. and Guilding, C. (2008) 'An exploratory investigation of an integrated contingency model of strategic management accounting', Accounting, Organizations and Society, 33(7-8). doi: 10.1016/j.aos.2008.01.003.

[15] Chi, V. T. Q. (2021) 'Study in the Factors Affecting the Application of Strategic Management Accounting (SMA) and Impacts on the Operating Accomplishments in the Manufacturing Enterprises in BAC Kan Province, Vietnam', The International Journal of Business \& Management, 9(1). doi: 10.24940/theijbm/2021/v9/i1/bm2101063.

[16] Chiu, J., Chung, H. and Hung, S.-C. (2021) 'Voluntary Adoption of Audit Committees, Ownership Structure and Firm Performance: Evidence from Taiwan', Emerging Markets Finance and Trade, 57(5), pp. 1514-1542. doi: 10.1080/1540496X.2019.1635449.

[17] Cinquini, L. and Tenucci, A. (2010) 'Strategic management accounting and business strategy: A loose coupling?', Journal of Accounting \& Organizational Change, 6(2). doi: 10.1108/18325911011048772.

[18] Dang Nguyen Manh (2019) Cost management accounting at enterprises producing construction ceramics and porcelain in Thai Binh province. University of Commerce.

[19] Darinskaya, V. V. et al. (2021) 'A targetcosting cost accounting system as a strategic management tool', in Studies in Systems, Decision and Control. doi: 10.1007/978-3030-57831-2_79.

[20] Deloitte (2014) Audit Committee Resource Guide.

[21] Dmitrović-Šaponja, L. and Suljović, E. (2017) 'Strategic management accounting in the Republic of Serbia', Economic Research-Ekonomska Istrazivanja , 30(1). doi: 10.1080/1331677X.2017.1392884.

[22] Dwekat, A. et al. (2020) 'Corporate Governance Configurations and Corporate Social Responsibility

[23] Disclosure: Qualitative Comparative Analysis of Audit Committee and Board characteristics', Corporate Social Responsibility and Environmental Management, 27(6), pp. 2879-2892. doi: 10.1002/csr.2009.

[24] Elad, F. L., Ngan, W. M. and Bongbee, N. S. (2017) 'The Role of Board Characteristics in Effective Corporate Governance: The Case of Airbus Group', SSRN Electronic Journal. doi: 10.2139/ssrn.2902928.

[25] F Neumann R Mautz (1977) Corporate Audit Committees: Policies and Practices. Ernst \& Ernst.

[26] Guilding, C., Cravens, K. S. and Tayles, M. (2000) 'An international comparison of strategic management accounting practices', Management Accounting Research, 11(1). doi: 10.1006/mare.1999.0120.

[27] Hadid, W. and Al-Sayed, M. (2021) 'Management accountants and strategic management accounting: The role of organizational culture and information systems', Management Accounting Research, $50 . \quad$ doi: 10.1016/j.mar.2020.100725.

[28] Hoang Thi Huyen (2018) Organization of management accounting information system to strengthen construction cost management in enterprises under Song Da Corporation. Academy of Finance.

[29] Hoang Thu Hien (2017) Cost management accounting in enterprises specializing in digital content business in Vietnam. Academy of Finance.

[30] Honggowati, S. et al. (2017) 'Corporate Governance and Strategic Management Accounting Disclosure', Indonesian Journal of Sustainability Accounting and Management, $\quad 1(1)$ doi: 10.28992/ijsam.v1i1.24.

[31] Khoo, E. S., Lim, Y. and Monroe, G. S. (2020) 'Audit Committee Members' Reputation Incentives and Their Effectiveness in Monitoring the Financial Reporting Process', Abacus, 56(3), pp. 348406. doi: 10.1111/abac.12201.

[32] KPMG's Audit Committee Institute (2017) Audit committee Guide.

[33] Langfield-Smith, K. (2008) 'Strategic management accounting: How far have we come in 25 years?', Accounting, Auditing and Accountability Journal, 21(2). doi: 10.1108/09513570810854400.

[34] Lee, J. and Park, J. (2019) 'The Impact of Audit Committee Financial Expertise on Management Discussion and Analysis (MD\&A) Tone', European Accounting Review, 28(1), pp. 129-150. doi: 10.1080/09638180.2018.1447387.

[35] Lynn, S. A. (1985) 'Audit Committees in Review: Their Impact on the CPA Selection Process', Ohio CPA Journal, 44(2), pp. 916.

[36] Medeckytè, K. and Tamulevičienè, D. (2020) 'Strategic management accounting: information application areas and instruments', Buhalterinès apskaitos teorija ir praktika, 21. doi: 10.15388/batp.2020.20. 
[37] Medeckyte, K. and Tamulevičienè, D. (2021) 'Research on the Awareness and Application of Strategic Management Accounting Instruments in Lithuanian Companies', Buhalterines apskaitos teorija ir praktika, (23). doi: 10.15388/batp.2020.29.

[38] Monks, R. A. . and Minow, N. (1995) Coporate Governance. Cambridge.

[39] Nguyen Minh Thanh (2017) Perfecting management accounting at units under Vietnam Oil and Gas Corporation. Academy of Finance.

[40] Nguyen Thi Duc Loan (2019) Factors affecting the application of cost management accounting in mining, processing and trading enterprises of construction stone in the Southeast provinces. University of Economics Ho Chi Minh City.

[41] Nixon, B. and Burns, J. (2012) 'The paradox of strategic management accounting', Management Accounting Research, 23(4). doi: 10.1016/j.mar.2012.09.004.

[42] Organization for Economic Cooperation and Development (OECD) (1999) Principles of Corporate Governance.

[43] Paul Collier (1992) Audit committees in large UK companies. Research Board of the Institue of Chartered Accountants in England and Wales.

[44] Pavlatos, O. (2015) 'An empirical investigation of strategic management accounting in hotels', International Journal of Contemporary Hospitality Management, 27(5). doi: 10.1108/IJCHM-12-2013-0582.

[45] Peter W. Wolnizer (1987) Auditing as Independent Authentication. Sydney University Press.

[46] Phornlaphatrachakorn, K. and NaKalasindhu, K. (2020) 'Strategic management accounting and firm performance: Evidence from finance businesses in Thailand', Journal of Asian Finance, Economics and Business, 7(8). doi: 10.13106/JAFEB.2020.VOL7.NO8.309.

[47] Ping, W. (2021) 'Data mining and XBRL integration in management accounting information based on artificial intelligence', Journal of Intelligent and Fuzzy Systems, 40(4). doi: 10.3233/JIFS-189509.

[48] PricewaterhouseCoopers (PwC) (2018) Audit committee Guide.

[49] Pylypiv, N. and Piatnychuk, I. (2018) 'Essential Strategic Management Accounting Tools Used for Making Investment Decisions at Enterprises in EU', Journal of Vasyl Stefanyk Precarpathian National University, 5(3-4). doi: 10.15330/jpnu.5.3-4.50-56.

[50] Raimo, N. et al. (2021) 'Do audit committee attributes influence integrated reporting quality? An agency theory viewpoint', Business Strategy and the Environment, 30(1), pp. 522-534. doi: 10.1002/bse.2635.

[51] Raweh, N. A. M. et al. (2021) 'Industry expertise on audit committee and audit report timeliness', Cogent Business and Management, 8(1). doi: 10.1080/23311975.2021.1920113.

[52] Thapayom, A. (2019) 'Strategic Management Accounting Techniques and Organizational Sustainable Performance: Evidence from Industrial Estates in Rayong Area, Thailand', Journal of Modern Management Science, 12(1).

[53] To Minh Thu (2019) Improving cost management accounting in Vietnamese paper manufacturing enterprises. Academy of Finance.

[54] Tran Hong, V. and Tran Thi Phuong, L. (2020) 'The Extent of Applying Strategic Management Accounting Tools in VietNam', Industry and Trade Magazine, 19. 